\title{
Fundamental Requirements for Smartphone Commercial Applications Development for Arabic Societies: Evidence from Three Gulf Cooperation Council States
}

\author{
Adel A. Bahaddad \\ Faculty of Computing and IT \\ King Abdulaziz University \\ Jeddah, Kingdom of Saudi Arabia \\ dbabahaddad10@kau.edu.sa
}

Date received: May 20, 2017

Date received in revised form: June 25, 2017

Date accepted: July 3, 2017

Recommended citation:

Bahaddad, A. A. (2017). Fundamental requirements for smartphone commercial applications development of Arabic societies: Evidence from three Gulf Cooperation Council states. International Journal of Computing Sciences Research, 1(1), 30-51. doi: 10.25147/ijcsr.2017.001.1.04

\begin{abstract}
Purpose - This study focuses on the requirements of commercial applications in the Arabic region, specifically in three Gulf Cooperation Council (GCC) states, which are Saudi Arabia (KSA), Qatar and the United Arab Emirates (UAE).

Method - It used quantitative survey to collect the opinion of the target audience in KSA, Qatar, and UAE.

Results - Identifying commercial application requirements in this study is necessary for two main reasons: first, current studies that present requirements are lacking; second, studies in this field vary from one region to another and from one community to another. Thus, identifying the requirements according to specific communities in this study will enable the broad use of the applications.

Contributions - The results provide 20 fundamental functions that should be included in m-commerce applications to be acceptable in Arabic society, as they may contribute to developing the mechanism of creating and designing smartphone commercial applications in developing companies. These functions are divided into three main parts; namely, technical, organisational and social functions.

Research Implications - These functions are influenced by various stakeholders such as consumers, sellers, and application designers. These three parties are the main decision makers about how to design the m-commerce application functions.
\end{abstract}

Keywords: commercial application, GCC, m-commerce, questionnaire survey, target characteristics

\section{INTRODUCTION}

Smartphone commercial applications currently appear to be one of the most important tools for the spread of electronic commerce (e-commerce). Commercial application is defined as compatible applications running within the smartphone environment to offer products or services, and completing the online purchasing through a variety of online payment methods. Many companies have invested in these applications in an effort to increase their customer bases through reaching larger segments of customers who cannot be accessed via traditional and non-electronic means (Bahaddad, Drew, Houghtoni, \& Alfarraj, 2015).The technical requirements associated with $\mathrm{m}$-commerce applications are of great importance from four different vantage points. 
Firstly, previous studies show a shortage in commercial application evaluations at the present time (e.g. Chang, Sun, Pan, \& Wang, 2015; Salameh, Hassan, Alekman, \& Alkafagi, 2015; Zahra, Khalil, \& Javed, 2013). Secondly, the requirements for smartphone commercial applications vary from one region to another and from one community to another due to different communities' characteristics. Thus, many studies have highlighted the impact of communities' characteristics and communities' requirements on the levels of acceptance of electronic systems, which include m-commerce applications (Abunadi, 2013; Hofstede, 2011). Thirdly, the commercial application developers require developing m-commerce applications to be compatible with the customers and companies need, which leads to increasing the level of acceptance and use by the target audience (Niranjanamurthy \& Kavyashree, 2013). Thus, it is important to identify the basic requirements for commercial applications in the Gulf region to ensure acceptance in the region. The main purpose for conducting this scientific study is to identify commercial application requirements that may contribute to the successful development of mobile commerce (m-commerce) approaches in the Arabic region. In addition, by providing a specific vision for the basic requirements for m-commerce applications motivating customers to engage in online purchasing by using commercial applications broadly is ensured (Salameh et al., 2015; Zahra et al., 2013).

This study was conducted in the Gulf Cooperation Council (GCC) to determine the functions that are important among Arabic communities that will help to contribute and increase their acceptance levels. Three GCC states were nominated because of their financial/economic positions. Moreover, these countries represent the top nations in the Arabic region for using smartphones (AlSuwaidan \& Mirza, 2014; eMarketer, 2015). It may be beneficial to expand these communities' experiences in the future to apply them on a wider scale across several expansion studies in the Arab region, using an integrated system compatible with the Arabic region's requirements for commercial applications.

The main outcome of this study was that emphasis be placed on the importance of 20 key functions to be included in designing products and services m-commerce applications. These functions include practical functions that application software companies must develop. They also include organisational functions, which depend on the opinions of companies about the online trading process. Finally, they also include social functions, which depend on consumers' views.The social functions are expected to increase clients' motivation to engage in online purchasing through smartphone commercial applications. For this reason, the main stakeholders should assume primary roles in the design of these functions to produce appropriate commercial applications that are compatible with the Arabic region's requirements and inspirations.

\section{LITERATURE REVIEW}

Many previous studies sought to identify the diverse requirements that should be provided in smartphones commercial applications. These studies varied with many topics that are covered in this study. The studies discussed in this section are about Mobile application requirements and design indicators that increase the effectiveness of m-commerce applications.

\section{Mobile application requirements}

Many studies in the area of mobile application evaluation focus on addressing the fundamental aspects governing ease of use and quality. There are various categoriesto determine the main factors that influence user acceptance. Alfahl, Sanzogni and Houghton (2012) noted that there are 15 factors which would be helpful to adopt in m-commerce. They are categorized into three main groups: environmental \& organizational, technological, and managerial (Alfahl et al., 2012; Bahaddad et al., 2015). Nielsen Norman Group (1994, cited by Harrison, Flood, \& Duce, 2013) notes that five key features should be available for all electronic applications on both websites and mobile applications. The following aspects are crucial for the acceptance of electronic applications:

1. Efficiency. This refers to compatible resources, accuracy, completeness of the basic requirements of applications, and achievement of the main design goal.

2. Satisfaction. This means customers should feel comfortable using the application and give positive feedback

3. Learnability. This implies learning the application should be quick and straightforward, and customers should be able to use it easily to accomplish tasks.

4. Memorability. This is evident in easy and quick storing and transferring of information. 
5. Errors. This suggest that the application should contain minimal errors, and that it should be easy to recover information (Garofalakis, Oikonomou, \& Stefanis, 2008; Nielsen Norman Group, 1994 cited by Harrison et al., 2013; Tsu Wei et al., 2008; Wong \& Hsu, 2008; Wu \& Wang, 2005).

Many of m-commerce commercial applications evaluation aspects present in previous points were considered important in some of previous studies. Each category of evaluation aspect is similar to the evaluation studies of commercial websites that were presented previously in this chapter.

People's perceptions about what the better the commercial application is are slightly different. Wang and Liao (2007) noted that mobile web commerce evaluation is based on many requirements, like the degree of m-commerce User Satisfaction (MCUS). Moreover, m-commerce applications are measured based on quality of content, quality of service, appearance, and ease of use (Wang \& Liao, 2007). Venkatesh, Ramesh and Massey (2003) pointed out the importance of understanding customers' requirements of m-commerce applications. These requirements should be keys to successful evaluation of commercial applications. There must also be continuous efforts to improve usability and user interfaces, which are responsible for helping generate a high percentage of mobile web business. It is also necessary to respond to users' feedback to ensure that their needs_-both functional and sensory_-are being met (Venkatesh et al., 2003).

\section{Design Indicators that Increase the Effectiveness of m-commerce Applications}

To provide consumers with many ways of accessing online stores, many previous studies have shown the importance of providing a variety of options for online purchases, such as e-commerce and m-commerce. So Wong and Hsu (2008) pointed out the importance of identifying factors that include cultural and social factors which help to increase the level of acceptance of m-commerce (Gefen, 2000; Salehi, Keramati, \& Didehkhani, 2010). Furthermore, some studies have indicated that trust between the consumer and the seller is increased over time so that a strong relationship is built between them. This is one of the main social factors in the acceptance of m-commerce (Wong \& Hsu, 2008).

Many studies on the relevant acceptance and adoption of online purchasing through commercial applications have focused on the framework and limitation of m-commerce to attain a better understanding of how to design these applications and fix programming bugs (Khalifa \& Ning Shen, 2008; Kourouthanassis \& Giaglis, 2012; Min, Ji, \& Qu, 2008; Sharma \& Gutiérrez, 2010; Varnali \& Toker, 2010). These studies contribute significantly to identifying the limitations and conditions that must be complied with to enable the smartphone commercial environment to reach a level of maturity. This maturity level features many levels, such as the institutional level, the level of production and the distribution level. It involves having knowledge of the requirements for making the right decision at the right time to meet the target population's needs (Barnes \& Vidgen, 2002; Büyüközkan, 2009; Kim, Mirusmonov, \& Lee, 2010).

Additionally, it should be noted that many of the indicators will be changed when the m-commerce applications' theoretical framework is revised according to the cultural and social perspectives of particular communities. In this study, the number of indicators collected is seven, with the indicators being divided into six main groups. These groups are the: Appearance (AP), Content (CO), Organisation (OR), Interaction (IN), Customer Focus (CF) and Assurance (AS) (See Figure 1) (Alotaibi, 2013; Barnes \& Vidgen, 2002; Büyüközkan, 2009). Each group includes a variety of indicators that help determine community requirements for commercial applications according to the views of the main stakeholders, namely, consumers, vendors and application developers.

\section{Appearance (AP)}

This part focuses on the appearance requirements of smartphone applications, which represent one way to attract new customers. A number of studies that confirmed the importance of attractive design application which encourage the target audience to adopt it (Barnes \& Vidgen, 2002; Hasan \& Abuelrub, 2011; Salameh et al., 2015; Zahra et al., 2013). There are 11 indicators that would measure appearance aspects in the commercial applications. These are innovative new design format (AP01), the importance of beautiful design (AP02), the importance to a balanced colours, images, and texts (AP03), balanced colours that are used in the screen interface so that no colour dominates the others (AP04), using combined expressive images and text links (AP05), using dark colour constrasted with light background, or vice versa (AP06), using no more than four different applications in each screen (AP07), using readable font type for users to ensure font consistentency (AP08), providing various options for display font sizes to accommodate of readers (AP09), not using more one 
title per screen in the application (AP10), and avoiding to use capital letters in normal text in English language (AP11).

\section{Content $(\mathrm{CO})$}

The applications content includes the information that should be presented in the application as well as the process information required of each screen in the application (Basu, 2003;Hasan \& Abuelrub, 2011; Jagoe, 2003; Mansour, 2014; Sohaib \& Kang, 2013; Khatib, 2013; Talib \& Faisal, 2015; Zambonini, 2015). There are 11 indicators to measure content part which are updating the application content generally (CO01), updating all application information such as new products that were added (CO02), showing the update time and date of each item (CO03), providing the information on the application's goals of the company (CO04), providing the facts about the company's services and activities provided to their client by the application (CO05), presenting information related to companies' products and services that can be offered by the application (CO06), providing application content free from spelling and grammatical errors (CO07), displaying the information regarding online legislation and policy in the company (CO08), easily getting the target audience the application in their specific area (CO09), making available the target audience main languages in the application (CO10), and creating alternative files formats such as PDF, video, and audio, that should be presented if an unexpected error appears in the application (CO11).

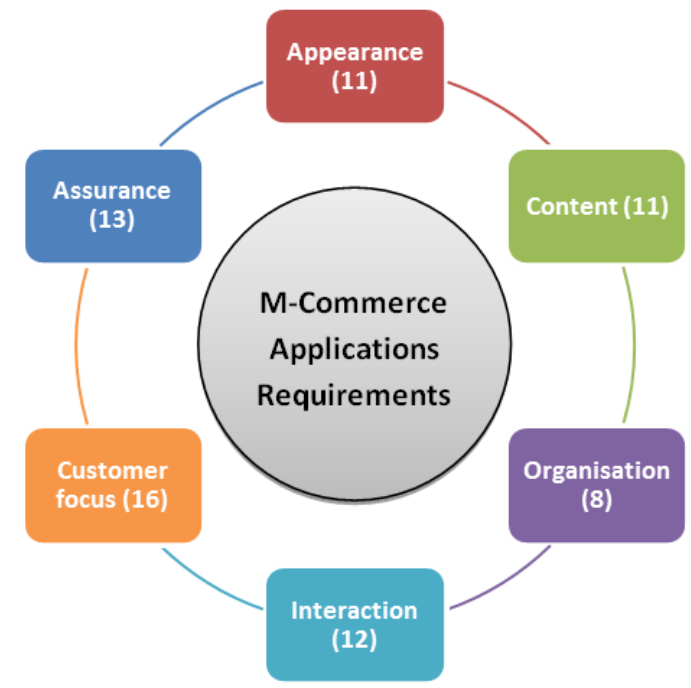

Figure 1. Main Groups of M-Commerce Applications Requirements

\section{Organisation $(O R)$}

The organization in the commercial application is important to increase the quality of performance and the seamless access to information in the application. Both sides would be helpful to increase consumer confidence in the smartphone applications particularly in commercial applications (Barnes \& Vidgen, 2002; Basu, 2003; Fitzpatrick, 2000; Mich, Franch, \& Gaio, 2003). The Organisation indicators can be measured in the applications according to eight indicators which are as follows: easy to remember and meaningful application name (OR01), display of the logo of the company in the application (OR02), the map that might be helpful to navigate among the screens and services in the application (OR03), the explicitly presented screen title (OR04), appropriately organized planning and design stages (OR05), alert messages provided or sent to communicate with clients regularly (OR06), fixed buttons in the main application's basic screens (OR07), basic features in the basic application that can be reached from anywhere in the application (OR08).

\section{Interaction (IN)}

The Interactive side in the smartphone commercial applications is one fundamental factor to the increased desire of people to use commercial applications. People prefer multimedia modes, like text, audio, photo, and video in commercial applications (Alba, Stay, \& Melia, 2013; Awamleh \& Fernandes, 2005; Pousttchi, Tilson, Lyytinen, \& Hufenbach, 2015). The interaction aspects can be measured within 12 indicators. They are using various multimedia elements such as images, video, and audio (IN01), using multimedia files with more than one option in each screen (IN02), creating effectively the multimedia files that are not affected 
in the download time (IN03), being available to change or rearranging the interface of application user like sorting the products on the display screen (IN04), displaying the result horizontally or vertically on the search screen (IN05), applying customised display by filtering the result of products and services (IN06), displaying special and different colours for result or background (IN07), sending messages of new release products to particular consumers to attract them to visit the application periodically (IN08), sending recommended messages to encourage customers to buy a particular product that might interesting for them (IN09), sending regular advertisements emails to active customers through their personal e-mails or social media accounts (IN10), using musical sound to alert the user for new actions or events in the application (IN11), and, finally, using the apps feature to play audio files of the smartphone OS when any information or offers are received (IN12).

\section{Customer Focus $(C F)$}

The communication with customers represents one of the fundamental aspects in the commercial application to increase the level of acceptance by the target audience. The appropriate mechanism to determine customer feedback is available in smartphones applications. Customer care is useful to raise the level of applications performance; these applications are beneficial to increase commercial and online trading. This leads to impact positively on the company's reputation and future plans (AlGhamdi, Alfarraj, \& Bahaddad, 2015; Bednall, 2013; Khan, Talib, \& Faisal, 2015; Lu, Huang, \& Tzeng, 2015; Pousttchi et al., 2015; Suki \& Suki, 2014; Wahab, Zahari, Al Momani, \& Nor, 2011; Zahra et al., 2013).

There are 16 indicators which represent the application customer focus measurement aspects. These indicators are channels to receive the complaints, suggestions, and customer feedback about the services or products (CF01, CF02, and CF03), loyalty reward programs for customers in the application such as receiving rewards for joining, improving company products or services, regular repeat visiting or purchasing via the application (CF04, CF05, and CF06), information of urgent assistance such as online chat and free hotlines (CF07), internal search capabilities in various application features (CF08), a list of FAQs and 'how to do' channel which include various formats, such as audio, documents, and video(CF09, and CF10), refund and exchange policies for products of the companies (CF11), follow up and tracking feature for customer products order until they received (CF12), e-receipts and e-invoice that are sent through emails or mobile messages (CF13), clear policies by the companies in the application to handle disputes in every stage of online purchasing process (CF14), several versions of smartphone application to compatible with various OS of smartphone devices (CF15), and customer service availability (CF16).

\section{Assurance $(A S)$}

Assurance aspects in the commercial application are important to increase the level of consumer confidence. They focus on the aspects that deal with ongoing online purchasing (Alfuraih, 2008; AlMamari, 2007; Joubert \& Belle, 2009; Lu et al., 2015; Mohamed \& Patel, 2015; Nelson, 2014; Pousttchi et al., 2015; Wahab et al., 2011; Zheng et al., 2015). There are 13 indicators to evaluate the assurance aspects. They include the following: providing various safety payment options (AS01), increasing customers' awareness of main threats in online shopping, determining these risks, and facing them through safe and logical solutions (AS02), presenting the security certificates in the application (AS03), displaying the security policy depending to countries' legislation (AS04), presenting the application's pass certification from smartphones' OS companies (AS05), providing temporary password via SMS to protect the personal information of clients if the device is stolen (AS06), providing passwords to login commercial applications (AS07), displaying confidential certificate of customers information recorded in the application (AS08), displaying privacy policies of the company that depends on the government legislation (AS09), ensuring that customer data are not saved via temporary files in the applications (AS10), providing contact information of the companies in case these are any questions or concerns by customers (AS11), presenting the copyright policy in the application for deter criminals to imitate or deceive the customers (AS12), providing the content details by providing alternative supportive sources, such as e-mail address, and physical address to increase the level of credibility in the applications (AS13).

\section{The Online Purchasing Process through Commercial Applications}

After presenting the fundamental indicators that should be provided in m-commerce applications, it is important to combine these indicators and the main steps that consumers should perform to complete online purchases through m-commerce application. Determining these key steps will help design the functions required for consumers and developer companies to make the use of commercial application easy (Awamleh \& Fernandes, 2005; Zahra et al.; 2013). A total of $93.5 \%$ of the study's participants believe in the importance of 
identifying the basic smartphone screens (see Figure 2) as well as additional basic symbols for moving from one application screen to another application screen. These symbols will be helpful in increasing smooth of applications use.

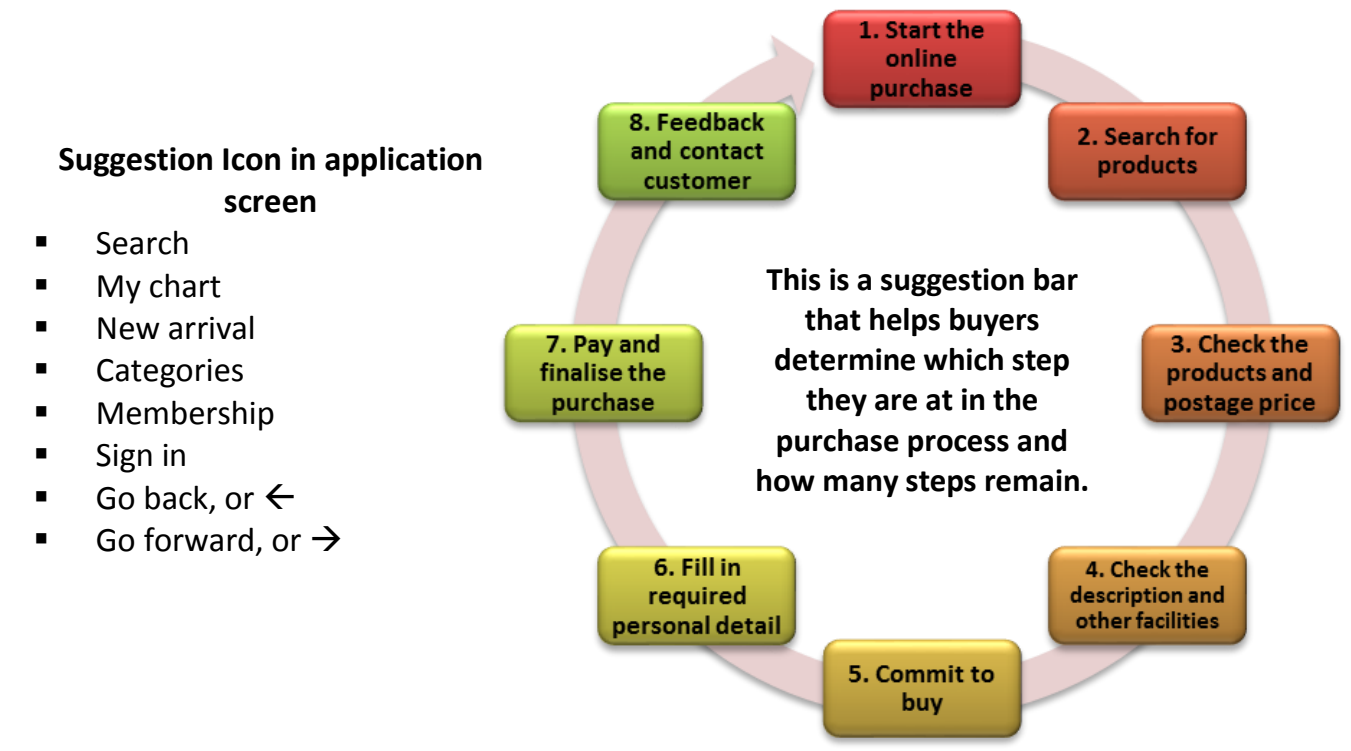

Figure 2. The proposal for an Online Purchasing Steps

\section{METHODOLDEY}

\section{Construction of Items}

The study tests the requirements of six groups that coming from literature review (AP, OR, CO, IN, $\mathrm{AS}$, and $\mathrm{CF}$ ), and the total of indicators is 71. These indicators are used to design the main functions of $\mathrm{m}-$ commerce applications that will be compatible with the GCC target audience aspirations.

\section{Data Gathering and Sample Size}

This study involved using a questionnaire, one of the most appropriate tools for gathering information from the target population. The lack of studies and lack of target awareness point to the importance of identifying the basic requirements for the sample to ensure that the right responses are obtained from the participants. Also, it is a good idea to create open-and-close questions to allow participants to share their knowledge about m-commerce. Therefore, the Likert scale was used to determine the participants' views through questions about the importance of these indicators. The questionnaire was distributed via electronic means (social media and various mailing lists) to reach a large segment easily (Creswell, 2008; Sekaran, 2003).

A total of 803 completed responses were obtained. The number of the sample size was calculated according to the level of confidence, which was $95 \%$, and the acceptable margin of error was $7.5 \%$. The participants were motivated by some incentives such as prizes and gift cards for participants who wished to enter the draw by providing communication means such as mobile or e-mail. This way has positive effect helpful to answering the questionnaires due to the length of the questionnaire which reach to 15 minutes. Furthermore, the questionnaire consists of three main sections that gathered demographic data (e.g., age, gender, and educational level), m-commerce experience (e.g., previous experience in m-commerce, residency status of GCC, and recency of purchases through at least once of the online purchasing channels), and perceptions towards m-commerce application requirements. Under consideration requirements, and open questions about any further requirements that were not highlighted during the questionnaire.

\section{Instrument Measurement Criteria}

Some measurements have been added to ensure that the questionnaire sentences are clear and correct. The measurements include arbitration by academic staff. Also, the questionnaire was translated into Arabic and 
then translated back into English through specialists to ensure that the sentences in the questionnaire have the correct meanings. Also, to ensure that appropriate participants were selected for the survey, three conditional questions were designed concerning: the participants' previous experience in m-commerce, residency status of GCC, and recency of purchases through at least one of the online purchasing channels. In addition, the survey included the purpose of the questionnaire and the contact information of the research team for any inquiries (Wuensch, 2005).

\section{Data Analysis}

This study dealt with statistical tests to reduce the number of indicators to a minimum number that can be used for designing commercial applications that can be compatible with the requirements of the Arabic communities in the Gulf region. Therefore, some tests were conducted, such as internal reliability, factor analysis, composite reliability (CR), and average variance extracted (AVE). More details about them are provided in the following sections.

\section{RESLLTS}

\section{Demographic Main Finding}

All participants represent a consumer demography that have sufficient experience of at least one online purchase. Sixty-one and three tenths percent (61.3\%) of respondents categorized themselves as male in the sample, while female respondents represent the remaining. As regards the question of educational level, the highest proportion of participants (more than 85\%) had a level of education of at least a Bachelor degree (the highest proportion of the study sample).

One of the main questions was about the type of smartphone device used. The question indicates the percentage of participants who have satisfactory experience with online purchasing transactions via smartphone, and who are familiar with aspects of the test indicators included in this study. The results show that more than 50\% use an Apple iPhone, more than 30\% use Samsung Galaxy while 20\% is distributed among other smartphone devices remaining on the list. Over $90 \%$ of participants have conducted an online transaction via smartphone devices.

In addition, participants responded to which consumer products categories they wanted to purchase online. These categories are ordered as follows: (1) electronic devices, (2) automobiles, (3) clothes, (4) beauty and health, (5) furniture and (6) jewellery (Bahaddad et al., 2014). All participants believed they have to have sources to support and encourage them to make online purchases. The most likely support reasons they have are previous awareness of online purchasing $(29.1 \%)$, cheap prices $(27.9 \%)$, reputation of online retailers $(29.2 \%)$ and friends' advice $(20.1 \%)$.

This study also found that many online activities were used continuously. The four most frequently used are e-mail (60.3\%), searching and browsing (56.9\%), social networking (55\%) and online video (54.31\%). Online seller suppliers take advantage of these main activities to advertise and promote products and market them via smartphones. For the study population, $47.2 \%$ of respondents spent less than 5 hours per day on Internet activities, while 25.43 of them spent between 5 and 9 hours per day on the Internet.

\section{Internal Consistency (Reliability scaling test)}

Consistency in the participants' answers is important. This is known as Factor Internal Consistency or Cronbach's alpha coefficient. It is the most common measure of internal consistency (Kline, 2005). A small value indicates heterogeneity and inconsistency; in contrast, a higher value indicates homogeneity and strong ability to represent the construct. The Cronbach's alpha level used in this study is 0.60 or above (Hair, Black, Babin, \& Anderson, 2010; Pallant, 2005). The result of internal consistency scale of the 6 group of indicators, represented by the 97 indicators proposed in Table 1 , shows level of values between $0.702 \& 0.893$. This indicates good internal consistency and reliability for study samples.

\section{Exploratory Factor Analysis (EFA)}

To achieve a summary of the experimental data sets, in this study, the factors were extracted using Principal Components Analysis (PCA) in SPSS. The Varimax orthogonal rotation is the preferred factor rotation 
method for this study because it is the simplest and most common of the factor analysis orthogonal rotation tools (Tabachnick \& Fidell, 2007). It also has a specific standard that can be used to justify the importance of a particular factor after the rotation process is completed. A factor rotation value of 0.50 or above is considered sufficient to get a power level greater than $80 \%$ with all the study samples together, which number 386 in the sample from KSA, 171 in the sample from Qatar, and 246 in the sample from UAE (Hair et al., 2010; Tabachnick $\&$ Fidell, 2007). The indicators with a factor loading test value of less than 0.50 have been excluded. The criteria and the EFA test procedures and the results are discussed in detail for each construct in the following sections.

\section{EFA, Composite Reliability (CR), and Average Variance Extracted (AVE) Results}

Based on the techniques and standards mentioned above, EFA was conducted on six groups of indicators which are AP, OR, CO, IN, AS, and CF. Some indicators were eliminated because of their weak result in the EFA test. All indicators that were accepted at this stage had a factor loading value of 0.5 or more. However, some indicators of lower values like AP06 $=0.428$ from AP group, OR01 =0.474, OR02 =0.479, and OR03 =0.470 from OR group were eliminated. Other indicators were also eliminated: $\mathrm{CO} 01=0.314, \mathrm{CO} 08=0.464, \mathrm{CO} 09=$ 0.424 from the CO group, AS01 $=0.408$ and AS13 =0.439 from the ASconstruct, and the IN01 $=0.404$ from IN group. In the Customer Focus group, four indicators were eliminated, namely, CF01 = 0.407, CF04=0.437, $\mathrm{CF} 11=0.450$, and $\mathrm{CF} 15=0.467$. The previous indicators were eliminated because their results have not met the minimum requirements of EFA.

The reliability of the model was evaluated using a more accurate measure which is known as CR. Also, the data is measured by The AVE which is used to calculate the variation in the variables that are used to measure the construct (Koufteros, 1999). The information in Table 1 indicates the relationship between the constructs in this study. Also, the AVE values are around 0.5 or above. All of the CR values ranged between 0.778 and 0.953 . Thus, the discriminant validity of the used indicators is sufficient for the requirements for commercial mobile applications in smartphones.

The results of group indicators in Table 1 represents the significant indicators to the target audience to accept and use the m-commerce application in GCC and should consider these indicators when designing the $\mathrm{m}$ commerce applications specially to companies in GCC or in applications that need to be used by GCC residences.

Table 1. Descriptive Statistics of All Indicators

\begin{tabular}{|c|c|c|c|c|c|c|c|c|c|c|c|c|c|c|c|}
\hline Code & Mean & SD & SE & FA & Alpha & CR & AVE & Code & Mean & SD & SE & FA & Alpha & CR & AVE \\
\hline AP01 & 4.49 & 0.59 & 0.037 & 0.635 & \multirow{9}{*}{0.718} & \multirow{9}{*}{0.805} & \multirow{9}{*}{0.503} & $\mathrm{CO} 02$ & 4.434 & 0.647 & 0.04 & 0.585 & \multirow{8}{*}{0.702} & \multirow{8}{*}{0.778} & \multirow{8}{*}{0.577} \\
\hline AP02 & 4.429 & 0.58 & 0.037 & 0.755 & & & & $\mathrm{CO} 03$ & 4.516 & 0.614 & 0.04 & 0.782 & & & \\
\hline AP03 & 4.371 & 0.62 & 0.04 & 0.744 & & & & $\mathrm{CO} 04$ & 4.279 & 0.714 & 0.044 & 0.642 & & & \\
\hline AP04 & 4.197 & 0.74 & 0.044 & 0.734 & & & & $\mathrm{CO} 05$ & 4.024 & 0.804 & 0.054 & 0.675 & & & \\
\hline AP05 & 4.037 & 0.83 & 0.054 & 0.519 & & & & $\mathrm{CO} 06$ & 4.108 & 0.787 & 0.05 & 0.714 & & & \\
\hline AP07 & 4.001 & 0.847 & 0.054 & 0.664 & & & & $\mathrm{CO} 07$ & 4.398 & 0.69 & 0.044 & 0.505 & & & \\
\hline AP08 & 4.088 & 0.847 & 0.054 & 0.768 & & & & $\mathrm{CO} 10$ & 4.356 & 0.707 & 0.044 & 0.781 & & & \\
\hline AP09 & 4.335 & 0.74 & 0.047 & 0.673 & & & & CO11 & 4.508 & 0.68 & 0.047 & 0.823 & & & \\
\hline AP11 & 3.971 & 0.847 & 0.054 & 0.645 & & & & IN02 & 4.294 & 0.68 & 0.044 & 0.576 & \multirow{11}{*}{0.736} & \multirow{11}{*}{0.808} & \multirow{11}{*}{0.562} \\
\hline OR04 & 4.415 & 0.617 & 0.037 & 0.741 & \multirow{6}{*}{0.744} & \multirow{6}{*}{0.837} & \multirow{6}{*}{0.548} & IN03 & 4.369 & 0.65 & 0.044 & 0.701 & & & \\
\hline OR05 & 4.448 & 0.58 & 0.037 & 0.741 & & & & IN04 & 4.665 & 0.54 & 0.037 & 0.619 & & & \\
\hline OR06 & 4.444 & 0.58 & 0.04 & 0.64 & & & & IN05 & 4.457 & 0.684 & 0.044 & 0.712 & & & \\
\hline OR07 & 4.439 & 0.644 & 0.04 & 0.636 & & & & IN06 & 4.399 & 0.66 & 0.04 & 0.61 & & & \\
\hline OR08 & 4.628 & 0.547 & 0.037 & 0.668 & & & & IN07 & 4.284 & 0.707 & 0.047 & 0.598 & & & \\
\hline OR09 & 4.664 & 0.534 & 0.034 & 0.694 & & & & IN08 & 4.075 & 0.79 & 0.05 & 0.514 & & & \\
\hline CF02 & 4.681 & 0.56 & 0.037 & 0.814 & \multirow{14}{*}{0.798} & \multirow{14}{*}{0.875} & \multirow{12}{*}{0.505} & IN09 & 4.06 & 0.777 & 0.05 & 0.673 & & & \\
\hline CF03 & 4.612 & 0.604 & 0.04 & 0.836 & & & & IN10 & 3.878 & 0.837 & 0.054 & 0.8 & & & \\
\hline CF05 & 4.493 & 0.747 & 0.047 & 0.848 & & & & IN11 & 3.784 & 0.824 & 0.05 & 0.778 & & & \\
\hline CF06 & 4.587 & 0.674 & 0.04 & 0.85 & & & & IN12 & 3.8 & 0.774 & 0.05 & 0.669 & & & \\
\hline CF07 & 4.437 & 0.724 & 0.047 & 0.727 & & & & AS02 & 4.793 & 0.467 & 0.03 & 0.624 & \multirow{10}{*}{0.893} & \multirow{10}{*}{0.935} & \multirow{10}{*}{0.59} \\
\hline CF08 & 4.32 & 0.704 & 0.047 & 0.747 & & & & AS03 & 4.674 & 0.567 & 0.037 & 0.718 & & & \\
\hline CF09 & 4.376 & 0.62 & 0.04 & 0.768 & & & & AS05 & 4.628 & 0.577 & 0.037 & 0.705 & & & \\
\hline CF10 & 4.394 & 0.65 & 0.04 & 0.72 & & & & AS06 & 4.671 & 0.557 & 0.037 & 0.801 & & & \\
\hline CF12 & 4.653 & 0.567 & 0.037 & 0.608 & & & & AS07 & 4.681 & 0.567 & 0.037 & 0.763 & & & \\
\hline CF13 & 4.697 & 0.54 & 0.034 & 0.728 & & & & AS08 & 4.685 & 0.57 & 0.037 & 0.699 & & & \\
\hline CF14 & 4.79 & 0.467 & 0.03 & 0.79 & & & & AS09 & 4.547 & 0.707 & 0.044 & 0.631 & & & \\
\hline CF16 & 4.648 & 0.577 & 0.037 & 0.707 & & & & AS 10 & 4.607 & 0.647 & 0.044 & 0.655 & & & \\
\hline & & & & & & & & AS11 & 4.732 & 0.577 & 0.037 & 0.611 & & & \\
\hline & & & & & & & & $\mathrm{AS} 12$ & 4.63 & 0.63 & 0.04 & 0.656 & & & \\
\hline
\end{tabular}




\section{DISCUSSIDN}

The indicators that help to determine the success of m-commerce applications have been presented briefly in the Literature review and have been analysed are relevant data in the analysis part. According to the result, there are number of indicators that have significant result to GCC. Furthermore, based on a number of studies that focus on the main stakeholders in the field of $\mathrm{m}$-commerce applications, there are three main groups that influence the decision to create and accept the m-commerce applications. These groups are consumer, seller, and developer (Bahaddad et al., 2015; Khan et al., 2015; Lu et al., 2015). These three groups of stakeholders have significantly influence the creation and design of the m-commerce applications functions which include the indicators of this study target audience. Thus, the study proposes to divide the m-commerce application functions into three types of functions based on the main stakeholders influence. The three different types of functions are technical, social, and organisational (Bahaddad et al., 2015).

Technical functions concentrate on purely technical functions of customer requirements and should be considered as purely technical aspects that help to automate the online purchasing process in the application. Organisational functions focus on the appropriate ways to order and organise information displayed in the applications. These functions depend on the regulatory requirements of companies; customers take them as they are without any opinion on them. Social functions help users decide to buy or not buy according to the information that would be added by previous customers about the products and feedback on any part of the product or the applications it contains (Alfahl et al., 2012; Sharma \& Gutiérrez, 2010; Tarasewich, Nickerson, \& Warkentin, 2002; Tsu Wei et al., 2009).

It is important to identify the requirements that are compatible with customer desires and to help customers smoothly and easily make good decisions through the e-commerce application. Some functions also apply to more than one of these three categories. Therefore, designing a function that includes all required information in one place (so it can be recalled every time someone needs to process user input to increase stability and perfect the performance of the application) would be helpful. Technical, social, and organisational requirements are all described in detail in the following section (see Tables 2 and 3 in Appendices).

\section{Technical Requirements}

From the customer's point of view, technical requirements can be considered as the technical aspects that customers need to make purchases via a specific vision of the customer. These functions, previously discussed with the online purchasing process through smartphone applications, is summarised as follows.

1. Design application style function: Focus on the design of the application, and how it works for people who have limited working experience with smartphone application designs. This function contains the following sub-elements:

- AP01 \& AP02: A general style of application based on innovation and beauty.

- AP03: Balance between the colours and the images including colour style to be used; also includes the ability to add colours, text, and images on each screen in the application.

- AP04: Diversity and balance in the colours used in the application's screens; recommends that no one colour be used more frequently than others.

- AP11: Avoidance of uppercase letters in English-language text.

- OR05: Organisation and consistency in the planning and design of the application as recommended in figure 2 .

- INO7: A variety of style displays, including choosing particular different colours for the background of the applications screens.

2. Design and application screens functions, which should contain the following points:

- AP05: Use of expressive images for the main service in the application instead of using texts, which give a clear indication of how the parts are connected. This function can provide designers several options for appropriate images that allow designers to choose from different choices.

- AP07: Selection and use of colours in the application screens for no more than four different colours.

- AP08: Use of specific types of Arabic or English fonts to ensure that the fonts are consistent and readable.

- AP09: Determination and change of text font size on-screen so it is more readable for the user.

3. OR09: Data entry function of required fields in the application;

4. AS09: Use of bilateral verification function which includes a temporary single SMS password that can be used after being admitted by basic user or using the finger print feature for smartphones.

5. AS11: Delete, for security purposes, cookies of consumers that are stored in the temporary files. 
6. CF13: The 'tracking shipping' item, which allows customers to follow up the shipping of products from within the application.

7. CF14: Provision of an electronic receipts feature which one can receive through email or SMS.

8. IN11 \& IN12: Provision of audio alert messages that help the user know what is new about applications through sound alert messages.

9. Display items/information on screen updated as follows:

- CO02: Regular update of information related to all items, like addition ofproduct and date.

- CO03: Time and date of last update for each item.

- CO06: Information about a company's best-selling products through the m-commerce application.

10. Functions relating to the presentation of multimedia files (text, video, image, voice) and to the professional design of these files so they do not take too long to load.

- IN02: Putting more than one option for multimedia on every screen and provision of a way to figure out how to operate a screen application through a "How do I do this?" feature.

- IN03: Building multimedia elements professionally so that they continue to download.

- CO11: Creation of files in a variety of alternative formats, including PDF, video, and audio, that would be presented in the application as alternative options if case of an unexpected error occurs.

11. CF16: Function that provides a diverse and compatible version of the application in smartphone devices and takes into account updates to the application that are compatible with any new versions or future of a given device or operating system.

The technical functions part contains 11 functions which is the largest number of functions in this model. These functions can be developed through practical research and designed, implemented, and tested on computers. Successful functions can be installed later in many applications or systems that require them. One example is a 'Tracking Shipped Item' function. This function concentrates on follow-up and providing essential shipping and arrival time information from inside the application such as DHL, TOLL, and SMSA Express.

Most tracking Item functions in commercial applications include a shipping item number and the shipping company along with the expected arrival date. Developing similar functions and presenting the results inside the application can be beneficial for shipping companies that can deploy the information widely through the function codes to companies that design their own applications. Consumer opinions are vital to the improvement of this and other technical functions. M-payment channels through credit cards from the application process without being moved online to the site of the financial firm being paid off; this function can be created and designed by the financial company to be added to the application. This code then completes the deduction from inside the application. Also, it can be designed as an e-wallet option which can be included in the application and connected to an official bank account in the financial companies (Chatain, 2008; Kim et al., 2010). This level of simplicity with technical application functions from inside the application has been suggested in other studies to increase the confidence of stakeholders. Overall, it can be expected that the level of confidence will increase if companies that own the application are able to communicate with their customers with respect for any event, error, mistake, concern, or enquiry that occurs during the online sales process (Pousttchi et al., 2015). This way, consumers can avoid being distracted by contact with the other relevant parties of the online purchasing process. Contact with consumers should be limited to the company's application, and the companies should be in contact with all other concerned parties to complete any enquiry related to the sales process, including banks, financial payment companies, shipping companies, Internet service companies, cloud storage, and commercial applications designers.

Other technical functions requirements concentrate on the applied complicate technical. These functions are contained in the design application style part that focuses on the applications' design, including functions that are concerned with colour lists and appropriate numbers on application screens. Furthermore, other functions concentrate more on activating the image in commercial applications than on using the texts as appropriate choices in GCC (Würtz, 2005). In addition, the user has the ability to increase and decrease the font size or use the zoom feature smoothly to make the text more readable. Moreover, the following features could be important and convenient also for users: toggling the keyboard between numeric and text screens, depending on the entered value; using a bilateral password to access confidential and payment account information; deleting temporary files when signing out an account; providing e-bills and e-receipts; providing the means to print the electronic document through the application process; providing various types of files to present the products (e.g., video, image, audio, or text); displaying the text in alternative formats like PDF files; displaying the regularly updated date and time of the application products and services; and using alert audio files to inform the user about receiving new announcements or information. These are the overall technical functions that are helpful to raise the level of user satisfaction and acceptance of m-commerce applications. It would be helpful to increase consumer conviction about the added value of the commercial application benefits that come from 
using the application regularly, because of the related Net benefits which lead to increased intention to re-use the commercial application in the future.

\section{Social Components}

Social functions help customers make decisions during online purchases by providing necessary information before, during and after the purchase. These functions focus on strengthening customers' confidence levels and providing alternatives and sufficient information on these alternatives in the form of feedback from former customers (Tarasewich et al., 2002). All of these functions are technological functions, as with all functions in this section; but they are placed in this group because they were created to serve the social element of online purchasing and to enhance the confidence of the target population. The functions can be summed up as follows.

12. Showing the recommended products that are in the users' interest area through Data Mining Technology.

- IN08: Providing selected products to customers that are of interest to them when they browse and search the application.

- IN09: Sending messages that include recommendations and advice to customers; these messages could include invitations to buy a particular product through the transmission of regular messages.

- IN10: Sending ads to customers through their personal email or social networking sites.

13. CO10: Determining the user's location through a Location Service to present available content based on geographical location.

14. Functions that build customer loyalty through periodic rewards programs.

- CF05: Giving rewards to customers who contribute to improve the company's products or services.

- CF06: Granting bonus to customers who regularly visit or purchase items through the company's mcommerce application.

15. Functions to communicate with customers and receive customers' suggestions and opinions about services and products offered.

- CF02 and CF03: Connecting with customers to receive customers' suggestions and opinions, as well as their views about the company's services and products.

- CF07: Function to provide online chat connection and free hot lines with customers, lending quick help and urgent solutions to problems.

16. AS03: Provides functionality that focuses on a 'feedback service', helping new customers find the views of former clients about the company's services and specific products.

The five functions under 'social functions' focus on the cultural target audience requirements. These functions are important for increasing consumer confidence in online purchasing through commercial applications. These functions concentrate on fully determining what consumers want in order to provide for their needs, thereby increasing their confidence in these applications (Pousttchi et al., 2015). This function builds communication bridges with customers regularly through many communication channels, through loyalty to customers via various points programs, and by displaying various products that might be of interest to consumers particularly, depending on personal data registered in the application and not from cookies files that are temporarily stored in the device (Wang, Lin, \& Luarn, 2006; Suki \& Suki, 2014; Wahab et al., 2011). As the cultural factors are important indicators in Arabic societies, these functions can directly affect how other functions work and, by extension (AlGhamdi, Nguyen, Ngueyn, \& Drew, 2011), the acceptance level by other interested parties of target audience requirements in commercial applications.

The social group is comprised of five basic functions, each containing some sub-functions, which collectively make up the consumer requirements affected by the cultural heritage of Arabic societies. These five functions are summarized as follows: displaying products that are more interesting to consumers through presenting the related products or goods via e-mail or other appropriate communication means; using service location technology, presenting products that have free shipping cost because they are located in or near the region where the consumers live; providing loyalty programs and regular reward points that increase the intention to use in the future; communicating with the target audience to provide quick and simple problem solving skills; and using the consumers' feedback to develop easy and convenient online purchase operations. These practical functions are significantly impacted by the target population's requirements, which lead to increasing the acceptance level of dealing with commercial applications. Thus, it is valuable to increase the performance level of these applications to make them more compatible with the target audience's requirements, thereby making their use more widespread. 


\section{Organisational Aspects}

Organisational functions focus on commercial application requirements that help companies organise needed information to reach them easily (Tarasewich et al., 2002). These requirements are helpful in providing information that helps the companies' client to deal with their applications since the clients are part of the User Satisfaction construct. These functions are presented here.

17. Functions relating to organisation and presentation of information in application screens that contain the following functions:

- OR04: Display page titles in the application screen clearly and allow the user to change the title formats.

- OR06: Design alert messages in the applications, focusing on the clarity of the information in the message box.

- OR07 \& OR08: Provide fixed icons for basic functions in the drop-down menu, slide menu, or on the bottom of all application screens, as well as easy access to these functions.

18. Search function assistance for quick learning of application characteristics. These functions are as follows:

- CF08: Internal search function in the application for information and various features of commercial applications.

- CF09: A FAQ list with answers.

- CF10: The 'How can I do this?'; Design, provide, and resolve any critical problems that pose challenges to customers. Video, audio, and text documentation is used to make these solutions as understandable as possible to the broadest group of users.

19. Display information function focuses on the display of detailed information about many important steps such as policies and knowledge. It is recommended that this function be shared from a screen in the application.

- CO04 \& CO05: Focuses on presenting company objectives and activities.

- CO07: Focuses on the spelling and grammatical errors in text to ensure an accurate and mistake-free text.

- AS02: Focuses on increasing consumer awareness by providing brief descriptions of the main threats to online purchasing via m-commerce with appropriate ways to solve these threats through safe and logical advice.

- AS05: Presents clear online commercial safety policy on application screens according to the legislation of countries where the application is used.

- AS06: Presents the privacy policy, which describes the importance of adhering to privacy laws and regulations adopted in countries where a given application is being used.

- AS08: Assists with the search results of internal application features.

- AS10: Provides the customers with a privacy certificate, informing them that their information is being held confidentially in the application.

- AS12: Presents the copyright policy of applications, preventing plagiarism in the application; also emphasises the importance of registering the application copyright in countries where the application is being used.

- AS13: Provides information about alternative contact resources for communicating with the company; initiates correspondence with e-mail, an address, and a hotline for ground line phone numbers.

- CF12: Presents company policies with respect to buying and selling to customers.

20. Function to display results; allows horizontal or vertical display of information and use of filtering techniques to sort data and display results for users.

- IN04: Function to change and rearrange the application interface options (such as sorting search results to protect and present sorted results according to name, price, or product).

- IN05: Function to display search results horizontally or vertically and compare the properties of different products through this display if needed.

- IN06: Function that displays search results using a filtering method for presenting products and services.

The four organisational functions are four functions that focus on customer needs and requirements and are related to companies' stated goal to make commercial applications more acceptable to target audience (Lin, Huarng, Chen, \& Lin, 2004; Joubert \& Belle, 2009). The development of these functions can be studied through market research and feasibility of projects from an investment perspective. The functions explain consumers' rights and obligations with companies and also explain electronic trading agreements, including what aspects the companies commit to with the online shopping process (Bahaddad et al., 2015). Furthermore, the application screens titles and messages to the user with the application capabilities that present the product's search results in many different ways. Associated user questions and answers can be shown according to customer requirements in the application. 
The organisational functions represent the functions that are determined to be the main requirements of companies that primarily operate electronic business applications. These organisational functions also do not require consumer opinion or need. This section includes four functions which are related to the display of the company's policies, which are important to consumers: the ability to display the titles for each screen in the application and to change the display according to user requirements; the ability to educate users about the many aspects of the online purchasing process; the ability to provide problem solving options to the users; and the ability to present search results to the consumer in different ways, horizontally or vertically, to meet consumer needs. These functions represent the desired integration between what the seller requires to complete the development of these applications. Also, it could help the consumers to know the company's policy clearly prior to purchase and thus help the consumers to make their right decision to use and spread the online purchasing approach widely. This might help to increase the acceptance level of the target audience in commercial applications, which reflects significantly on consumer satisfaction and leads to the Intention to Use the commercial application. Furthermore, the added value in the organisational functions should be highlighted by identifying consumers' requirements that would be helpful to make their right decision to go forward with online purchasing in particular application or moving to another option of online shopping. Therefore, the important part in the added value need not be implemented by uninterested parties or wrong target customers, which lead to an expanded lifecycle for design and to the implementation of the commercial application, as well as an increase of time needed to accept the application by the target audience. This reason might reduce companies' desire to develop their applications in the future, an indication of how companies perform to look after their clients and solve their problems. Indifference to customers welfare may result into negative interest of consumers toward specific commercial applications to a level that cannot be solved easily in future.

The following tables (Tables 2, 3, and 4) show functions and related groups that could be the link to continuing the wheel of development and integration between the consumer, seller, and developers. Thus, it is important to consider the variety of these functions and the design of the framework that helps provide integration in commercial applications. The functions in this part are divided into technical, social, and organisational groups.

\section{Summary of the Proposed Functions in the Framework of Commercial Smartphones Depending on the Requirements of Individual GCC Countries}

The following Tables 2, 3, and 4 in Appendices provide a basic summary of the functions that are part of the online purchasing steps. These functions are divided into eight basic steps required to complete the purchase process (See figure 2). Also included in the function are the new group names according to functions, namely technical, organisational, or social category (see Table 2). In addition, table 3 presents the functions that influence all online purchasing steps as well as the relative screens that were presented previously in Figure 2.

This section covers the last research questions and provides more detail about the main research aspects. It is important to determine the design considerations of m-commerce applications that are compatible with the Arabic societies because of possible commercial values.

- These requirements are significant to consumers, the ultimate target audience (since, without consumers, there is no m-commerce). It is important to focus on the target audiences' needs, including what functions they require, what specifics are contained in these functions, and who is primarily served by a particular function. This knowledge is important for companies that design applications (and any of their investors), and assists in determining the level of importance to consumers of each function. The main purpose of technical functions is to transfer manual work to an electronic environment. It is important to automate the online purchasing to m-commerce application according to the requirements and desires of the main stakeholders who need to be determined before the functions are implemented. Thus, the regulatory functions depend on what the companies need in order to present the main information in commercial application screens, while the social functions concentrate on assisting consumers with decision-making by determining their requirements in commercial applications.

- As presented in Tables 1,2, and 3 in Appendices, these functions can be divided into two main parts. The first part consists of functions that impact specific screens in several steps according to Table 2. The second part includes functions that impact all application screens with no exceptions; these functions appear in Table 3. Furthermore, these functions are presented with their goals; the groups they belong to, including function code; and where the functions impact online purchasing steps. This classification helps identify functions that have a long-term impact (shown in Table 3), or that present conflict between the input or output stages with any short-term impacts of functions on input and output as (shown in Table 2). These functions, then, primarily serve to integrate the work of other, smaller-scale functions. 
Integration of technical, social, and organisational functions is important. These three categories comprise a wide part of the fundamental requirements consumers have with respect to m-commerce applications. Strong integration elevates consumer confidence and level of acceptance of the application, even in cases where some of the target audience are not interested. Increasing acceptance and confidence leads to increased sales and wide dissemination of a culture of online purchasing.

\section{IMPLICATIONS}

Several implications were noted in this study. These are as follows:

- Customer requirements for each part of AP, OR, CO, IN, AS, and CF should be improved to acceptable levels for customers, because customers can simply reject a purchase from any place with the use of the internet, this may affect a company's reputation (Rämänen, Riihiaho, Erkkilä, \& Seppälä, 2011). In the long-term, companies can continue the e-commerce and m-commerce relationship with the consumers to either exchange the material or switch to another company (Ho et al., 2009; Anderson \& Srinivasan, 2003; Rämänen et al., 2011). It would be helpful to let the competitive advantage stay between the competitors' parties that because this will be more advantageous to the customers. It will be their demands that will be satisfied or met. Thus, improving the online purchasing products and m-commerce systems would and could increase acceptance of the products without using an ill-considered price by the companies. In addition, customers will be more loyal to the companies and will patronize their products.

- The growing development of electronic systems for the conduct of m-commerce and acceptance of various models in commercial applications, indicates recognition of the various dimensions of $\mathrm{NB}$ and other outcomes of m-commerce approaches; this is particularly true of GCC countries, which have shown a growing interest in smartphone devices. The growing development of electronic systems also increased online business in these countries in the past decade to appropriate levels that will create strategies to improve incomplete success variables that effect GCC societies in particular (Alpen Capital, 2011; Hu, AlGahtami, \& Hu, 2010).

- The expected impact on the initiatives for quality improvement affects Customer Satisfaction. It is important to consider the improvement aspects that result from customer feedback, because they are helpful in the development of m-commerce systems and operating systems on which smartphones are dependent (Alotaibi, 2013; Piao, Wang, Wan, \& Luo, 2012). They assist the diffuse e-commerce transformation approach to $\mathrm{m}$-commerce environments. Furthermore, the disadvantage of ignoring important dimensions for customers will lead to the possibility of increased customer departures to other companies. It directly impacts basic resource strategies of e-commerce, which decrease the number of customers who use particular m-commerce Application (Alwahaishi \& Amine, 2014; Woodruff, 1997). This leads to the best option for m-commerce systems in regard to consumer behaviour. It might be important to explore aspects of customer requirements that cannot be achieved in the appropriate time to ensure the preservation of existing customers and to gain good reputation that would be help to gain new customers in the future through word of mouth from current customers.

\section{CONCLUSIDN}

This study focused on identifying and analysing the technical features, or various functions, to be integrated when designing smartphone commercial applications. Thus, these proposals might be helpful for identifying the fundamental requirements for both buyers and sellers online to determine what they want in commercial applications like reducing the amount of design time needed. In addition, this approach will contribute to automated e-commerce systems across commercial applications significantly. The "test" and "modify" stages of commercial applications consume a considerable amount of effort and time, which reflects negatively on the interaction of companies when dealing with electronic trading channels and investment in online procurement. Because the study focused primarily on facilitating commercial application efforts, it might positively affect the quality of the output of the beneficiaries to spread commercial applications widely. Likewise, this study will contribute to a variety of future studies, like contributing to specialised applications to be completed online and in specific business activities that are appropriate for Arabics. Consequently, these applications will contribute to reaching a high level of success by providing various approaches for commercial applications to smoothly and easily work together in the same electronic environment. This will ultimately boost the proliferation of $\mathrm{m}$-commerce through commercial applications, which will have good returns and revenues in the future. 


\section{REFERENCES}

Abunadi, I. (2013). Influence of culture on e-government acceptance in Saudi Arabia (Doctoral dissertation). Griffith University. Retrieved from https://arxiv.org/ftp/arxiv/papers/1307/1307.7141.pdf

Alba, J., Stay, J., \& Melia, R. (2013). I'm on Facebook--Now what???: How to use Facebook to achieve business objectives. California, USA: Happy About.

Alfahl, H., Sanzogni, L., \& Houghton, L. (2012). Mobile Commerce Adoption in Organizations: A Literature Review and Future Research Directions. Journal of Electronic Commerce in Organizations (JECO), 10(2), 61-78.

Alfuraih, S. I. (2008). E-commerce and e-commerce fraud in Saudi Arabia: A case study. In International Information Security and Assurance, 2008 (pp. 176-180). NJ: IEEE. doi: 10.1109/ISA.2008.45

AlGhamdi, R., Alfarraj, O. A., \& Bahaddad, A. A. (2015). How retailers at different stages of e-commerce maturity evaluate their entry to e-commerce activities?. Journal of Computer Science and Information Technology, 2(2), 37-71.

AlGhamdi, R., Nguyen, A., Nguyen, J., \& Drew, S. (2011). Factors influencing Saudi customers' decisions to purchase from online retailers in Saudi Arabia: A quantitative analysis. Paper presented at the IADIS International Conference e-Commerce Rome, Italy. Retrieved from https://researchrepository.griffith.edu.au/bitstream/handle/10072/45338/73571_1.pdf?sequence=1

AlMamari, M. (2007). Mobile commerce development in Oman (Unpublished master's thesis). The University of Sheffield. Retrieved from http://dagda.shef.ac.uk/dissertations/2006-07/External/AlMamari_Mohammed_MScIS.pdf

Alotaibi, M. (2013). E-commerce adoption in Saudi Arabia: An assessment of international, regional and domestic web presence. International Journal of Information Technology and Computer Science, 5(2), 42-56.

Alpen Capital. (2011). GCC retail industry November 1, 2011. Retrieved from http://www.alpencapital.com/downloads/GCC\%20Retail\%20Industry\%20Report\%202011_1\%20Novem ber\%202011.pdf.

AlSuwaidan, L., \& Mirza, A. A. (2014). An investigation on user preferences of mobile commerce interface design in Saudi Arabia. Lecture Notes in Computer Science, 8640, 275-285. doi: 10.1007/978-3-31910359-4 22.

Alwahaishi, S., \& Amine, N. T. (2014). Opportunities and challenges for the electronic commerce deployment in developing countries discussed in a case of Saudi Arabia. In Encyclopedia of Information Science and Technology. (3rd ed., pp. 2339-2350). Hershey, PA: IGI Global. doi: 10.4018/978-1-4666-5888-2.ch227

Anderson, R. E., \& Srinivasan, S. S. (2003). E-satisfaction and e-loyalty: a contingency framework. Psychology and Marketing, 20(2), 123-138.

Awamleh, R. \& Fernandes, C., (2005). Internet Banking: An empirical investigation into the extent of adoption by banks and the determinants of customer satisfaction in the United Arab Emirates. Journal of Internet Banking and Commerce. Retrieved April 30, 2016, from http://www.arraydev.com/ commerce/JIBC/2005-02/raedcedwyn1.HTM

Bahaddad, A. A., AlGhamdi, R., \& Alkhalaf, S. (2014). Adoption factors for e-malls in the SME sector in Saudi Arabia. International Journal of Computer Science and Information Technologies, 5(4), 5835-5856.

Bahaddad, A. A., Drew, S., Houghtoni, L., \& Alfarraj, O. A. (2015). Factors attracting online consumers to choose e-Malls for e-procurement in Saudi Arabia. Enterprise Information Systems, 1-32. doi: $10.1080 / 17517575.2015 .1091952$

Barnes, S. J. \& Vidgen, R. T., (2002). An integrative approach to the assessment of e-commerce quality. Journal of Electronic Commerce Research, 3(3), 114-127.

Basu, A. (2003). Context-driven assessment of commercial web sites. Paper presented at the 36th Annual Hawaii International Conference on System Sciences, Hawaii, USA. doi: 10.1109/HICSS.2003.1174475

Bednall, D. (2013). Expert marketing evidence. Expert Evidence, 1-86.

Büyüközkan, G. (2009). Determining the mobile commerce user requirements using an analytic approach. Computer Standards \& Interfaces, 31(1), 144-152. doi: 10.1016/j.csi.2007.11.006

Chang, S. C., Sun, C. C., Pan, L. Y., \& Wang, M. Y. (2015). An Extended TAM to Explore Behavioural Intention of Consumers to Use M-Commerce. Journal of Information \& Knowledge Management, 1550014.

Chatain, P.-L. (2008). Integrity in mobile phone financial services: Measures for mitigating the risks from money laundering and terrorist financing. Washington, D.C. USA: World Bank Publications.

Creswell, J. W. (2002). Creswell, J. W. (2008). Educational research: Planning, conducting, and evaluating qualitative and quantitative research. Columbus, OH USA: Merrill Prentic.

eMarketer. (2015). Smartphones, mobile commerce roundup. Retrieved May 21, 2016, from https://www.emarketer.com/public_media/docs/eMarketer_Mobile_Commerce_Roundup.pdf 
Fitzpatrick, R. (2000). Additional quality factors for the world wide web. Paper presented at the 2nd World Congress for Software Quality, Tokyo, Japan.

Garofalakis, J., Oikonomou, F., \& Stefanis, V. (2008). System's Design and Implementation for Easy Creation of Mobile Commerce Systems. 2008 Third International Conference on Internet and Web Applications and Services. Retrieved June 15, 2016, from http://ieeexplore.ieee.org/lpdocs/epic03/ wrapper.htm?arnumber $=4545601$

Gefen, D. (2000). E-commerce: The role of familiarity and trust. Omega, 28(6), 725-737.

Hair, J. F., Black, W., Babin, B., \& Anderson, R. (2010). Multivariate data analysis: a global perspective (7th ed.). New Jersey: Pearson.

Harrison, R., Flood, D., \& Duce, D. (2013). Usability of mobile applications: Literature review and rationale for a new usability model. Journal of Interaction Science, 1(1), 1-16.

Hasan, L., \& Abuelrub, E. (2011). Assessing the quality of web sites. Applied Computing and Informatics, 9(1), 11-29.

Hofstede, G. (2011). Dimensionalizing cultures: The Hofstede model in context. Online Readings in Psychology and Culture, 2(1), Article 8. doi: 10.9707/2307-0919.1014

Hu, H.-f., Al-Gahtani, S. S., \& Hu, P. J.-H. (2010). Examining gender effects in technology acceptance by Arabian workers: A survey study. Paper presented at the PACIS 2010. Retrieved from http://aisel.aisnet.org/pacis2010/76

Jagoe, A. (2003). Mobile location services: Text (Vol. 1). New Jersey, USA: Prentice Hall Professional.

Joubert, J., \& Belle, J. P. V. (2009). The importance of trust and risk in m-commerce: A South African perspective. Paper presented at PACIS 2009. Retrieved from http://aisel.aisnet.org/pacis2009/96

Khalifa, M., \& Ning Shen, K. (2008). Explaining the adoption of transactional B2C mobile commerce. Journal of Enterprise Information Management, 21(2), 110-124.

Khan, H., Talib, F., \& Faisal, M. N. (2015). An analysis of the barriers to the proliferation of m-commerce in Qatar: A relationship modeling approach. Journal of Systems and Information Technology, 17(1), 54-81.

Khatib. (2013). Gulf states exceed the proportion of expats cap.. and the UAE on top. Retrieved May 15, 2017 from http://www.aleqt.com/2013/10/16/article_793189.html

Kim, C., Mirusmonov, M., \& Lee, I. (2010). An empirical examination of factors influencing the intention to use mobile payment. Computers in Human Behavior, 26(3), 310-322.

Kline, R. B. (2005). Principles and Practice of Structural Equation Modeling (2nd ed.). New York: Guilford Press.

Koufteros, X. A. (1999). Testing a model of pull production: a paradigm for manufacturing research using structural equation modeling. Journal of Operations Management, 17(4), 467-488.

Kourouthanassis, P. E., \& Giaglis, G. M. (2012). Introduction to the special issue mobile commerce: The past, present, and future of mobile commerce research. International Journal of Electronic Commerce, 16(4), $5-18$.

Lin, F., Huarng, K., Chen, Y., \& Lin, S. (2004). Quality evaluation of web services. Paper presented at IEEE International Conference on E-Commerce Technology for Dynamic E-Business, Beijing, China

Lu, M. T., Hu, S. K., Huang, L. H., \& Tzeng, G. H. (2015). Evaluating the implementation of business-tobusiness m-commerce by SMEs based on a new hybrid MADM model. Management Decision, 53(2), 290-317.

Mansour, Y. (2014). Regulating payments for M-Content: The positive impact of the deregulation. International Review of Law, 9, 1-12. doi: 10.5339/irl.2014.9

Mich, L., Franch M., \& Gaio, L. (2003). Evaluating and designing web site quality. IEEE Multimedia, 10(1), 34-43.

Min, Q., Ji, S., \& Qu, G. (2008). Mobile commerce user acceptance study in China: a revised UTAUT model. Tsinghua Science \& Technology, 13(3), 257-264.

Mohamed, I., \& Patel, D. (2015). Android vs iOS security: A comparative study. Paper presented at the 2015 12th International Conference on Information Technology - New Generations (ITNG), Las Vegas, NV, USA. doi: 10.1109/ITNG.2015.123

Nelson, P. (2014). How to turn on Android encryption today (no waiting necessary). Retrieved May 17, 2016 from http://www.greenbot.com/article/2145380/why-and-how-to-encrypt-your-android-device. html

Niranjanamurthy, M., \& Kavyashree, N. (2013). Analysis of e-commerce and m-commerce: Advantages, limitations and security issues. International Journal of Advanced Research in Computer and Communication Engineering, 2(6), 2360-2370.

Nielsen Norman Group. (2013). Mobile website and application usability. Retrieved May 22, 2016, from http://www.nngroup.com/reports/mobile-website-and-application-usability/

Pallant, J. (2005). SPSS Survival Manual: A Step by Step Guide to Data Analysis using SPSS for Windows (Version 12). Berkshire: Open University Press. 
Piao, C., Wang, S., Wen, J., \& Luo, Y. (2012). Mobile commerce trust model and its application for third party trust service platform. Paper presented at the 2012 IEEE 14th International Conference on Commerce and Enterprise Computing (CEC), Hangzhou, China. doi: 10.1109/CEC.2012.27

Pousttchi, K., Tilson, D., Lyytinen, K., \& Hufenbach, Y. (2015). Introduction to the special issue on mobile commerce: Mobile commerce research yesterday, today, tomorrow-what remains to be done?. International Journal of Electronic Commerce, 19(4), 1-20.

Rämänen J., Riihiaho S., Erkkilä M., Seppälä A. (2011) User Studies on Mobile Ticketing. In: Marcus A. (eds) Design, User Experience, and Usability. Theory, Methods, Tools and Practice. DUXU 2011. Lecture Notes in Computer Science, vol 6769. Berlin, Heidelberg: Springer.

Salameh, A. A., Hassan, S., Alekam, J. M., \& Alkafagi, A. A. C. (2015). Assessing the effect of service quality and information quality on customers' overall perceived service quality in m-commerce. Australian Journal of Basic and Applied Sciences, 9(13), 146-153.

Salehi, M., Keramati, A., \& Didehkhani, H. (2010). A framework for investigating mobile web success in the context of e-commerce an analytic network process (ANP) approach. Journal of Computing Science and Engineering, 4(1), 53-79.

Sekaran, U. (2003). Research methods for business: A skill building approach. Journal of Education for Business, 68(5), 316-317.

Sharma, S., \& Gutiérrez, J. A. (2010). An evaluation framework for viable business models for m-commerce in the information technology sector. Electronic Markets, 20(1), 33-52.

Sohaib, O., \& Kang, K. (2013). The importance of web accessibility in business to-consumer (B2X) websites. Paper presented at the 22nd Australasian Software Engineering Conference (ASWEC 2013). Retrieved from http://aswec2013.ict.swin.edu.au/ASWEC2013-PhD-Symposium/papers/paper_2.pdf

Suki, N. M., \& Suki, N. M. (2014). Mobile social networking service users' trust and loyalty. In J. Wei (Ed.), Mobile electronic commerce: Foundations, development, and applications (pp. 89-106). Boca Raton, FL: CRC Press.

Tabachnick, B. G., \& Fidell, L. S. (2007). Using Multivariate Statistics. Boston: Pearson Education, Inc.

Talib, F., \& Faisal, M. (2015). An analysis of the barriers to the proliferation of m-commerce in Qatar. Journal of Systems and Information Technology, 17(1), 54-81.

Tarasewich, P., Nickerson, R. C., \& Warkentin, M. (2002). Issues in mobile e-commerce. Communications of the Association for Information Systems, 8(1), 41-64. Retrieved from http://aisel.aisnet.org/cais/vol8/iss1/3

Tsu Wei, T., Marthandan, G., Yee-Loong Chong, A., Ooi, K. B., \& Arumugam, S. (2009). What drives Malaysian m-commerce adoption? An empirical analysis. Industrial Management \& Data Systems, 109(3), 370-388.

Varnali, K., \& Toker, A. (2010). Mobile marketing research: The-state-of-the-art. International Journal of Information Management, 30(2), 144-151.

Venkatesh, V., Ramesh, V., \& Massey, A. P. (2003). Understanding usability in mobile commerce. Communications of the ACM, 46(12), 53-56.

Wahab, S., Zahari, A. S. M., Al Momani, K., \& Nor, N. A. M. (2011). The influence of perceived privacy on customer loyalty in mobile phone services: An empirical research in Jordan. International Journal of Computer Science Issues, 8(2), 45-52.

Wang, Y. S., Lin, H. H., \& Luarn, P. (2006). Predicting consumer intention to use mobile service. Information Systems Journal, 16(2), 157-179.

Wang, Y.-S., \& Liao, Y.-W. (2007). The conceptualization and measurement of m-commerce user satisfaction. Computers in Human Behavior, 23(1), 381-398.

Wong, Y. K., \& Hsu, C. J. (2008). A confidence-based framework for business to consumer (B2C) mobile commerce adoption. Personal and Ubiquitous Computing, 12(1), 77-84.

Woodruff, R. B. (1997). Customer value: the next source for competitive advantage. Journal of the Academy of Marketing Science, 25(2), 139-153.

Wu, J. H., \& Wang, S. C. (2005). What drives mobile commerce?: An empirical evaluation of the revised technology acceptance model. Information \& management, 42(5), 719-729.

Wuensch, K. (2005). What is a Likert scale? and how do you pronounce 'Likert?. East Carolina University. Retrieved June 12, 2016 from http://core.ecu.edu/psyc/ wuenschk/StatHelp/Likert.htm.

Würtz, E. (2005). A cross-cultural analysis of websites from high-context cultures and low-context cultures. Journal of Computer-Mediated Communication, 11(1), 1-23. Retrieved May 2, 2016, from http://jcmc.indiana.edu/vol11/issue1/wuertz.html

Zahra, S., Khalid, A., \& Javed, A. (2013). An efficient and effective new generation objective quality model for mobile applications. International Journal of Modern Education and Computer Science (IJMECS), 5(4), $36-42$. 
Zambonini, P. (2015). Payments innovations and trends in the Gulf Cooperation Council. Journal of Payments Strategy \& Systems, 9(1), 59-78.

Zheng, M., Xue, H., Zhang, Y., Wei, T., \& Lui, J. C. (2015). Enpublic Apps: Security threats using iOS enterprise and developer certificates. In Proceedings of the 10th ACM Symposium on Information, Computer and Communications Security (pp. 463-474). ACM. doi: 10.1145/2714576.2714593

\section{APPENDICES}

Table 2. Summary of main functions and their distribution across the main constructs of the IS Model

\begin{tabular}{|c|c|c|c|c|c|c|c|c|c|c|c|c|c|c|c|c|c|c|c|c|c|}
\hline & 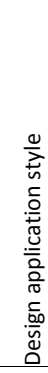 & 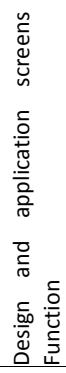 & 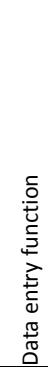 & 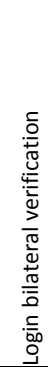 & 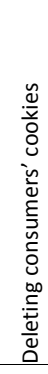 & 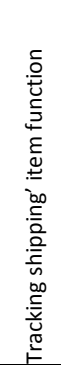 & 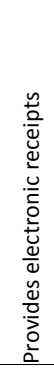 & 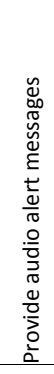 & 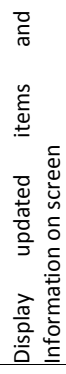 & 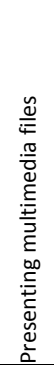 & 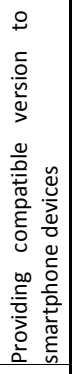 & 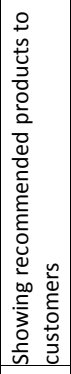 & 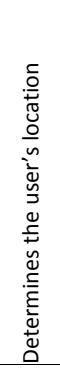 & 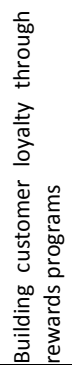 & 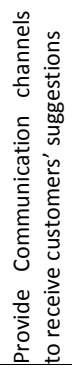 & 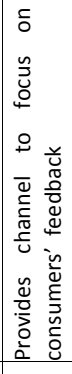 & 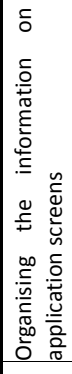 & 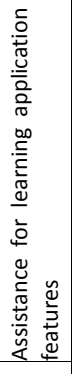 & 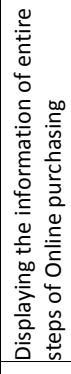 & 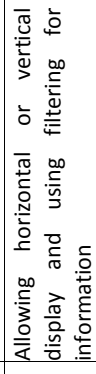 \\
\hline & & 1. & 2. & 3. & 4. & 5. & 6. & 7. & 8. & 9. & 10. & 11. & 12. & 13. & 14. & 15. & 16. & 17. & 18. & 19. & 20. \\
\hline & & \multicolumn{11}{|c|}{ Technical Requirements (6.1) } & \multicolumn{5}{|c|}{ Social Components (6.2) } & \multicolumn{4}{|c|}{ Organisational Aspects (6.3) } \\
\hline \multirow{8}{*}{ 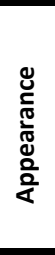 } & AP01 & 0 & & & & & & & & & & & & & & & & & & & \\
\hline & AP02 & 0 & & & & & & & & & & & & & & & & & & & \\
\hline & AP03 & 0 & & & & & & & & & & & & & & & & & & & \\
\hline & AP04 & 0 & & & & & & & & & & & & & & & & & & & \\
\hline & $\frac{\mathrm{AP05}}{\mathrm{AP07}}$ & & 0 & & & & & & & & & & & & & & & & & & \\
\hline & AP08 & & 0 & & & & & & & & & & & & & & & & & & \\
\hline & AP09 & & 0 & & & & & & & & & & & & & & & & & & \\
\hline & AP11 & 0 & & & & & & & & & & & & & & & & & & & \\
\hline \multirow{6}{*}{ 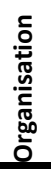 } & OR04 & & & & & & & & & & & & & & & & & 0 & & & \\
\hline & OR05 & 0 & & & & & & & & & & & & & & & & & & & \\
\hline & OR06 & & & & & & & & & & & & & & & & & 0 & & & \\
\hline & OR07 & & & & & & & & & & & & & & & & & 0 & & & \\
\hline & OR08 & & & & & & & & & & & & & & & & & 0 & & & \\
\hline & OR09 & & & 0 & & & & & & & & & & & & & & & & & \\
\hline \multirow{8}{*}{ ثัّ } & $\mathrm{CO} 2$ & & & & & & & & & 0 & & & & & & & & & & & \\
\hline & $\mathrm{COO3}$ & & & & & & & & & 0 & & & & & & & & & & & \\
\hline & CO04 & & & & & & & & & & & & & & & & & & & 0 & \\
\hline & CO05 & & & & & & & & & & & & & & & & & & & 0 & \\
\hline & CO06 & & & & & & & & & 0 & & & & & & & & & & & \\
\hline & CO07 & & & & & & & & & & & & & & & & & & & 0 & \\
\hline & $\mathrm{CO} 10$ & & & & & & & & & & & & & 0 & & & & & & & \\
\hline & CO11 & & & & & & & & & & 0 & & & & & & & & & & \\
\hline \multirow{10}{*}{ 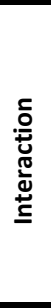 } & IN02 & & & & & & & & & & 0 & & & & & & & & & & \\
\hline & IN03 & & & & & & & & & & 0 & & & & & & & & & & \\
\hline & IN04 & & & & & & & & & & & & & & & & & & & & 0 \\
\hline & IN05 & & & & & & & & & & & & & & & & & & & & 0 \\
\hline & IN06 & & & & & & & & & & & & & & & & & & & & 0 \\
\hline & IN07 & 0 & & & & & & & & & & & & & & & & & & & \\
\hline & IN09 & & & & & & & & 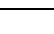 & & & & 0 & & & & & & & & \\
\hline & IN10 & & & & & & & & & & & & 0 & & & & & & & & \\
\hline & IN11 & & & & & & & & O & & & & & & & & & & & & \\
\hline & IN12 & & & & & & & & 0 & & & & & & & & & & & & \\
\hline \multirow{9}{*}{ 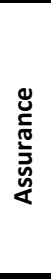 } & AS02 & & & & & & & & & & & & & & & & & & & 0 & \\
\hline & ASO3 & & & & & & & & & & & & & & & & 0 & & & & \\
\hline & AS05 & & & & & & & & & & & & & & & & & & & 0 & \\
\hline & AS06 & & & & & & & & & & & & & & & & & & & 0 & \\
\hline & AS08 & & & & & & & & & & & & & & & & & & & 0 & \\
\hline & AS09 & & & & 0 & & & & & & & & & & & & & & & & \\
\hline & $\begin{array}{l}A S S 11 \\
A S 1\end{array}$ & & & & & 0 & & & & & & & & & & & & & & 0 & \\
\hline & AS12 & & & & & & & & & & & & & & & & & & & 0 & \\
\hline & AS13 & & & & & & & & & & & & & & & & & & & 0 & \\
\hline \multirow{11}{*}{ 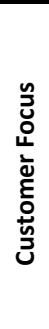 } & CF02 & & & & & & & & & & & & & & & 0 & & & & & \\
\hline & CF03 & & & & & & & & & & & & & & & 0 & & & & & \\
\hline & CF05 & & & & & & & & & & & & & & 0 & & & & & & \\
\hline & CF06 & & & & & & & & & & & & & & 0 & & & & & & \\
\hline & CF07 & & & & & & & & & & & & & & & 0 & & & & & \\
\hline & CF08 & & & & & & & & & & & & & & & & & & 0 & & \\
\hline & $\begin{array}{l}\text { CC09 } \\
\text { CF10 }\end{array}$ & & & & & & & & & & & & & & & & & & $\frac{0}{0}$ & & \\
\hline & CF12 & & & & & & & & & & & & & & & & & & & 0 & \\
\hline & CF13 & & & & & & 0 & & & & & & & & & & & & & & \\
\hline & CF14 & & & & & & & 0 & & & & & & & & & & & & & \\
\hline & CF16 & & & & & & & & & & & 0 & & & & & & & & & \\
\hline
\end{tabular}


Table 3. Summary of All Commercial Smartphone Application Requirements

\begin{tabular}{|c|c|c|c|}
\hline $\begin{array}{c}\text { Online Purchasing } \\
\text { steps }\end{array}$ & $\begin{array}{c}\text { Indicator } \\
\text { code }\end{array}$ & Function Details & $\begin{array}{c}\text { Function } \\
\text { Code }\end{array}$ \\
\hline \multirow{23}{*}{$\begin{array}{l}\text { Start }+ \\
\text { assistance } \\
\text { information }(1 \\
\text { of } 8)\end{array}$} & CF05 & $\begin{array}{l}\text { Display customers' contribution reward points for improving the } \\
\text { company application in the starting screen }\end{array}$ & F14 Social \\
\hline & CF06 & $\begin{array}{l}\text { Display customers' reward points for visiting or purchase through } \\
\text { the application }\end{array}$ & F14 Social \\
\hline & CF08 & $\begin{array}{l}\text { Provide application map to help the users know how they can reach } \\
\text { and search application internal features }\end{array}$ & F18 Org. \\
\hline & CF09 & $\begin{array}{l}\text { Provide a list of Frequently asked questions (FAQ) and their } \\
\text { answers }\end{array}$ & F18 Org. \\
\hline & CF10 & $\begin{array}{l}\text { Provide a screen that helps to answer the question, "How do I do } \\
\text { this?" and present related information to solve this problem which } \\
\text { should be supported by multimedia formats (video, documents, etc.) }\end{array}$ & F18 Org. \\
\hline & CF12 & $\begin{array}{l}\text { Display the company policies for the online buying and selling } \\
\text { process to customers clearly }\end{array}$ & F19 Org. \\
\hline & $\mathrm{CO} 04$ & $\begin{array}{l}\text { Provide information about the company's goals and online } \\
\text { applications shopping objective }\end{array}$ & F19 Org. \\
\hline & $\mathrm{CO} 05$ & Provide information about the company's activities and services & F19 Org. \\
\hline & CO06 & $\begin{array}{l}\text { Present the products that sell the most through the application and } \\
\text { online channels }\end{array}$ & F09 Tech. \\
\hline & CO07 & $\begin{array}{l}\text { Provide free content in the start and assistance screens for spelling } \\
\text { and grammatical errors }\end{array}$ & F19 Org. \\
\hline & CO11 & $\begin{array}{l}\text { Provide the content in the start and assistance screen in alternative } \\
\text { formats, such as PDF, video, and audio format }\end{array}$ & F10 Tech. \\
\hline & IN02 & Provide more than one multimedia option to display products & F10 Tech. \\
\hline & IN03 & $\begin{array}{l}\text { Ensure the file of multimedia elements in the start and assistance } \\
\text { screen is built professionally for ease of download }\end{array}$ & F10 Tech. \\
\hline & IN08 & Advise customers of products that are of personal interest & F12 Social \\
\hline & IN09 & $\begin{array}{l}\text { Send promotions via e-mail and other smartphone communication } \\
\text { channels to customers regularly }\end{array}$ & F12 Social \\
\hline & IN10 & $\begin{array}{l}\text { Rotate ads to customers via their personal online contact, such as e- } \\
\text { mail or social networking application }\end{array}$ & F12 Social \\
\hline & IN11 & $\begin{array}{l}\text { Use auditory stimuli such as musical tones with events and new } \\
\text { news to keep in touch with consumers }\end{array}$ & F08 Tech. \\
\hline & IN12 & $\begin{array}{l}\text { Use symbols/icons to run audio files or visual features so users can } \\
\text { choose between reading, listening to, or watching their news }\end{array}$ & F08 Tech. \\
\hline & AS02 & $\begin{array}{l}\text { Increase consumer awareness by providing brief descriptions of the } \\
\text { main threats in mobile shopping and present safe and logical } \\
\text { solutions }\end{array}$ & F19 Org. \\
\hline & $\begin{array}{l}\text { AS05 } \\
\qquad \begin{array}{l}\text { AS06 } \\
\text { ASO }\end{array}\end{array}$ & $\begin{array}{l}\text { Present security and privacy policies for the online commercial } \\
\text { aspect clearly on a branched screen from the Start and assistance } \\
\text { screen according to the legislation of countries where the } \\
\text { application is used }\end{array}$ & F19 Org. \\
\hline & AS08 & $\begin{array}{l}\text { Obtain an application pass certificate from Smartphone companies } \\
\text { such as Apple Store \& Google Play Store and present it on a } \\
\text { branched screen from the Sort and assistance screen }\end{array}$ & F19 Org. \\
\hline & AS09 & $\begin{array}{l}\text { Use bilateral verification passwords for customers through short text } \\
\text { messages on a mobile after application sign-in }\end{array}$ & F04 Tech. \\
\hline & AS10 & $\begin{array}{l}\text { Display privacy policy to customers for the information that is } \\
\text { saved in the confidential and encrypted storage }\end{array}$ & F19 Org. \\
\hline
\end{tabular}


Table 4. Summary of All Commercial Smartphone Application Requirements (cont.)

\begin{tabular}{|c|c|c|c|}
\hline \multirow{11}{*}{$\begin{array}{l}\text { Search for } \\
\text { products } \\
(20 f 8)\end{array}$} & OR09 & $\begin{array}{l}\text { Change the keyboard to numbers and letters to write the names of } \\
\text { products in the application database. }\end{array}$ & F05 Tech. \\
\hline & $\mathrm{CO} 02$ & $\begin{array}{l}\text { Provide regular product information updates (including the product } \\
\text { name and date added) }\end{array}$ & F09 Tech. \\
\hline & $\mathrm{CO} 03$ & $\begin{array}{l}\text { Provide relative information for searching and products which } \\
\text { include Last update, and number of products are available for online } \\
\text { sell }\end{array}$ & F09 Tech. \\
\hline & $\mathrm{CO} 06$ & $\begin{array}{l}\text { Information about products that sell the most through the } \\
\text { application during searches for particular products }\end{array}$ & F09 Tech. \\
\hline & $\mathrm{CO} 07$ & $\begin{array}{l}\text { Ensuring the content is free from spelling and grammatical errors in } \\
\text { the Search for products screen. }\end{array}$ & F19 Org. \\
\hline & IN03 & $\begin{array}{l}\text { Ensure the multimedia elements are built professionally for ease of } \\
\text { download in the Search for products screen. }\end{array}$ & F10 Tech. \\
\hline & IN04 & $\begin{array}{l}\text { Display options of research result can be changed or rearranged } \\
\text { Colour of research result }\end{array}$ & F20 Org. \\
\hline & IN05 & Provide the display search results horizontally or vertically & F20 Org. \\
\hline & IN06 & The ability to represent search results through particular filters & F20 Org. \\
\hline & IN08 & $\begin{array}{l}\text { Present relevant products and advise the customers of some } \\
\text { examples of personal interest }\end{array}$ & F12 Social \\
\hline & AS09 & $\begin{array}{l}\text { Ensure the customers have personal Accounts and Log-ins to } \\
\text { receive the right personal interest option in the Search for products } \\
\text { screen }\end{array}$ & F04 Tech. \\
\hline \multirow{9}{*}{$\begin{array}{l}\text { Check the } \\
\text { prices } \\
(3 \text { of } 8)\end{array}$} & $\mathrm{CO} 02$ & $\begin{array}{l}\text { Present and update essential product information (e.g. Price, } \\
\text { Availability, Colour, Size and ... etc.) }\end{array}$ & F09 Tech. \\
\hline & $\mathrm{CO} 03$ & $\begin{array}{l}\text { Provide the last date and time of information updated to clarify the } \\
\text { availability }\end{array}$ & F09 Tech. \\
\hline & $\mathrm{CO} 07$ & $\begin{array}{l}\text { Ensure the content is free from spelling and grammatical errors in } \\
\text { the Check the price Screen }\end{array}$ & F19 Org. \\
\hline & $\mathrm{CO} 11$ & $\begin{array}{l}\text { Provide the product information and description in alternative } \\
\text { formats, such as PDF, video, and audio format }\end{array}$ & F10 Tech. \\
\hline & IN02 & Provide more than one multimedia option to display products & F10 Tech. \\
\hline & IN03 & $\begin{array}{l}\text { Ensure multimedia elements are built professionally for ease of } \\
\text { download in the Check the price screen }\end{array}$ & F10 Tech. \\
\hline & IN04 & $\begin{array}{l}\text { Application display options can be changed, coloured or rearranged } \\
\text { in the display view }\end{array}$ & F20 Org. \\
\hline & IN05 & $\begin{array}{l}\text { The ability to display search results horizontally or vertically in the } \\
\text { Check the price screen }\end{array}$ & F20 Org. \\
\hline & IN08 & $\begin{array}{l}\text { Advise customers of products that are of personal interest in the end } \\
\text { of screen as alternative options }\end{array}$ & F12 Social \\
\hline \multirow{7}{*}{$\begin{array}{l}\text { Check the } \\
\text { description } \\
\text { (4 of } 8)\end{array}$} & $\mathrm{CO} 02$ & $\begin{array}{l}\text { Present regular product information updates to ensure the customer } \\
\text { read right information about the products date added) }\end{array}$ & F09 Tech. \\
\hline & $\mathrm{CO} 07$ & $\begin{array}{l}\text { Ensure the content is free from spelling and grammatical errors in } \\
\text { the Check the description screen }\end{array}$ & F19 Org. \\
\hline & CO11 & $\begin{array}{l}\text { Provide the description content in alternative formats, such as PDF, } \\
\text { video, or audio format }\end{array}$ & F10 Tech. \\
\hline & IN02 & Provide some other multimedia options to display products & F10 Tech. \\
\hline & IN03 & $\begin{array}{l}\text { Ensure the multimedia elements are built professionally for ease of } \\
\text { download in the Check the description screen }\end{array}$ & F10 Tech. \\
\hline & IN04 & $\begin{array}{l}\text { Application display options can be changed to other colours and the } \\
\text { display rearranged }\end{array}$ & F20 Org. \\
\hline & IN05 & The ability to display search results horizontally or vertically & F20 Org. \\
\hline
\end{tabular}


Table 5. Summary of All Commercial Smartphone Application Requirements (cont.)

\begin{tabular}{|c|c|c|c|}
\hline \multirow{3}{*}{$\begin{array}{l}\text { Commit to buy } \\
(5 \text { of } 8)\end{array}$} & OR09 & Changing the keyboard to numbers to enter the quality of products. & F05 Tech. \\
\hline & IN08 & Advising customers of products that are of personal interest & F12 Social \\
\hline & IN09 & $\begin{array}{l}\text { Sending promotions and vouchers via e-mail to be used in the } \\
\text { Purchasing screen regularly }\end{array}$ & F12 Social \\
\hline \multirow{2}{*}{$\begin{array}{l}\text { Fil Personal } \\
\text { info. ( } 6 \text { of } 8)\end{array}$} & CO11 & $\begin{array}{l}\text { Providing content in alternative formats to be chosen if the } \\
\text { application breakdown or not responses such as website and PDF } \\
\text { files }\end{array}$ & F10 Tech. \\
\hline & IN02 & $\begin{array}{l}\text { Provision of more than one multimedia option to teach the } \\
\text { customers how they can fill the required information for online } \\
\text { purchasing through the application. }\end{array}$ & F10 Tech. \\
\hline \multirow{5}{*}{$\begin{array}{l}\text { Checkout } \\
\text { (7 of 8) }\end{array}$} & OR09 & $\begin{array}{l}\text { Changing the keyboard to numbers and letters depending on the } \\
\text { input type for each field of credit card details }\end{array}$ & F05 Tech. \\
\hline & IN02 & $\begin{array}{l}\text { Provide some multimedia options to learn how the customers they } \\
\text { can make checkout correctly }\end{array}$ & F10 Tech. \\
\hline & AS03 & $\begin{array}{l}\text { The application should include communication channels to ascertain } \\
\text { customers' opinions about the company's services and products } \\
\text { about all the previous steps }\end{array}$ & F16 Social \\
\hline & CF13 & $\begin{array}{l}\text { Display customers' tracking items that are purchased until the items } \\
\text { are received in the application screen. }\end{array}$ & F06 Tech. \\
\hline & CF14 & $\begin{array}{l}\text { Design, provide, and display electronic receipts as PDF files, } \\
\text { emails, or mobile messages }\end{array}$ & F07 Tech. \\
\hline \multirow{6}{*}{$\begin{array}{l}\text { Feedback and } \\
\text { Contact } \\
\text { customer } \\
(8 \text { of } 8)\end{array}$} & OR09 & $\begin{array}{l}\text { Change the keyboard to numbers and letters to write down the } \\
\text { customer feedback and experience about the products and } \\
\text { application performance }\end{array}$ & F05 Tech. \\
\hline & AS03 & $\begin{array}{l}\text { Provide a form or survey about the company and their application } \\
\text { performance and the company's services and products }\end{array}$ & F16 Social \\
\hline & CF02 & $\begin{array}{l}\text { Provide channels to receive customer suggestions and comments } \\
\text { through the application. }\end{array}$ & F15 Social \\
\hline & CF03 & $\begin{array}{l}\text { Provide direct communication channels to obtain customers' } \\
\text { opinions about company services and products }\end{array}$ & F15 Social \\
\hline & CF05 & $\begin{array}{l}\text { Send notification of reward customers who contribute to improving } \\
\text { company products via applications }\end{array}$ & F14 Social \\
\hline & CF07 & $\begin{array}{l}\text { Provide online chat and toll-free telephone lines for any assistance } \\
\text { to customers. }\end{array}$ & F15 Social \\
\hline
\end{tabular}


Table 6. Summary of All Commercial Smartphone Application Requirements that Affect All Approach Screens Together

\begin{tabular}{|c|c|c|c|}
\hline \multicolumn{2}{|c|}{ Indicator code } & Function Details & $\begin{array}{l}\text { Function } \\
\text { Code }\end{array}$ \\
\hline \multirow{7}{*}{ 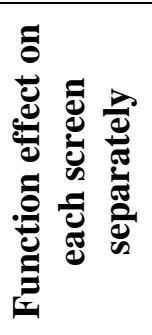 } & AP07 & Using no more than four different colours per screen & F02 Tech. \\
\hline & AP09 & Using appropriate size of font for Smartphone screen reader & F02 Tech. \\
\hline & AP11 & Avoiding using capital letters extensively in normal text in English language & F01 Tech. \\
\hline & OR04 & Providing information about the company's application goals & F17 Org. \\
\hline & OR06 & Clarity and meaningfulness of the application's alert messages & F17 Org. \\
\hline & OR07 & Providing icons for fundamental functions in most basic application screens & F17 Org. \\
\hline & OR08 & $\begin{array}{l}\text { Ease of access to the main functions from anywhere on the application's } \\
\text { screens }\end{array}$ & F17 Org. \\
\hline \multirow{13}{*}{ 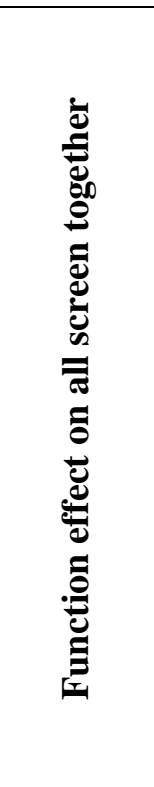 } & AP01 & Using new and innovative design to build the commercial applications & F01 Tech. \\
\hline & AP02 & Design beauty to attract the Smartphone application customers & F01 Tech. \\
\hline & AP03 & The fundamental balance between colours, images and text & F01 Tech. \\
\hline & AP04 & $\begin{array}{l}\text { The balancing colours that are used on the screen interface; and one should } \\
\text { not use any colour more than the others }\end{array}$ & F01 Tech. \\
\hline & AP08 & Using a particular font type to ensure the text is consistent and readable & F02 Tech. \\
\hline & OR05 & Organising and consistency in planning and design & F01 Tech. \\
\hline & AP05 & Using expressive images instead of using text links only & F02 Tech. \\
\hline & $\mathrm{CO} 10$ & $\begin{array}{l}\text { Providing application languages according to the target audience in a } \\
\text { specific geographic area }\end{array}$ & F13 Social \\
\hline & IN07 & Use of special colours and display methods in the application background & F01 Tech. \\
\hline & AS11 & Customer data should not be kept in temporary application files & F05 Tech. \\
\hline & AS12 & $\begin{array}{l}\text { Emphasising copyright policy to prevent impersonators from using the same } \\
\text { applications or deceiving customers via false websites or applications }\end{array}$ & F19 Org. \\
\hline & AS13 & $\begin{array}{l}\text { Increase the credibility of application content by providing alternative } \\
\text { contact details for company/consumer communications }\end{array}$ & F19 Org. \\
\hline & CF16 & $\begin{array}{l}\text { Providing versions of smartphones application to be compatible with all } \\
\text { purchasing screens, features, and functions that are working in the } \\
\text { application }\end{array}$ & F11 I \\
\hline
\end{tabular}

